\title{
Peningkatkan Kemampuan Berhitung Permulaan Melalui Media Sempoa
}

\author{
Erna Olua, Diana Setyaningsih, Yohana B. Pabendan
}

PG PAUD Universitas Cenderawasih Jayapura

Jl. Kamp Wolker, Jl. Kambolker Perumnas III, Yabansai, Heram, Jayapura City, Papua 99224 E-mail: erna.olua@gmail.com

\begin{abstract}
Article Info
Abstract

Received Desember 2019

Accepted Februari 2020

The purpose of this study was to describe the increase in numeracy skills of Published April 2020

0-10 through the Abacus Media for Group B children in Integrated PAUD Nagallo Marannu, Puncak Jaya Regency, Academic Year 2017/2018. This research was conducted on group B children, amounting to 16 people. This

Keywords: research is an action research with the method of Kemmis and Taggart which consists of 4 stages, namely (plan, act, observe and reflect). This Ability to Count, Abacus study consisted of 2 cycles, each of which consisted of 3 meetings. Data Media, Early Childhood. collection techniques using observation, field notes, and documentation. Data analysis using quantitative and qualitative. Quantitative data analysis was performed with statistical descriptions to compare pre-cycle to cycle II. Qualitative analysis is carried out by analyzing data from observations, field notes and verified documentation. The results showed that there was an increase in the ability to count numbers 0-10 through the abacus media with a score in the pre-cycle of $46.35 \%$ increasing to $66.66 \%$ in the first cycle and an increase of 82.29 in the second cycle with the very well developed category.
\end{abstract}

\begin{abstract}
Abstrak : Tujuan dari penelitian ini adalah mendeskripsikank mengetahui peningkatan kemampuan berhitung Angka 0-10 Melalui Media Sempoa Pada Anak Kelompok B di PAUD Terpadu Nagallo Marannu Kabupaten Puncak Jaya Tahun Ajaran 2017/2018. Penelitian ini dilakukan pada anak kelompok B yang berjumlah 16 orang. Penelitian ini adalah penelitian tindakan dengan metode Kemmis dan Taggart yang terdiri dari 4 tahap yaitu (rencana, tindakan, observasi dan refleksi). Penelitian ini terdiri dari 2 siklus masing-masing siklus sebanyak 3 pertemuan. Teknik pengumpulan data menggunakan observasi, catatan lapangan, dan dokumentasi. Analisis data menggunakan kuantitatif dan kualitatif. Analisis data kuantitatif dilakukan dengan deskripsi statistik untuk membandingkan pra siklus sampai siklus II. Analisis kualitatif dilakukan dengan menganalisis data dari observasi, catatan lapangan dan dokumentasi yang telah diverifikasi. Hasil penelitian menunjukkan terdapat peningkatan kemampuan berhitung angka 0-10 melalui media sempoa dengan skor pada pra siklus $46,35 \%$ meningkat menjadi $66,66 \%$ pada siklus I dan mengalami peningkatan sebesar 82,29 pada siklus II dengan kategori berkembang sangat baik.
\end{abstract}

Kata kunci : Kemampuan Berhitung, Media Sempoa, Anak Usia Dini 


\section{PENDAHULUAN}

Berhitung di Taman kanak - Kanak diharapkan tidak hanya berkaitan dengan kemampuan kognitif saja, tetapi juga kesiapan mental, social dan emosional. Pembelajaran berhitung di TK hanya diajarkan berhitung awal yaitu penambahan dan pengurangan 1-10, membilang dengan benda-benda 1 20, menyebutkan urutan bilangan 1 - 20, memasangkan lambang bilangan dengan benda $1-20$, meniru lambang bilangan dengan benda $1-10$, mampu membedakan 2 kumpulan benda sama jumlahnya, tidak sama jumlahnya, banyak dan sedikit jumlahnya. Oleh karena itu dalam pelaksanaannya, berhitung di taman Kanak-Kanak dilakukan secara menarik dan bervariasi.

Berdasarkan pengamatan saya di di PAUD Terpadu Nagallo Marannu Kabupaten Puncak Jaya Tahun Ajaran 2017/2018. Pada kelompok B dengan jumlah anak 16 orang. 10 anak laki-laki dan 6 anak perempuan hal ini sangat jauh dari harapan. Di PAUD Terpadu Nagallo Marannu ini terdapat 10 orang anak (75\%) yang teramati rendah dalam Kemampuan menyebut bilangan 1-10, Kemampuan penjumlahan bilangan 1-10, Kemampuan pengurangan bilangan $1-10$.

Hal ini disebabkan oleh dua faktor yaitu faktor internal dan eksternal, Faktor eksternal yaitu guru kurang kreatif memilih media pembelajaran yang tepat, kurangnya media pembelajaran, dimana selama ini guru dalam pelaksanaan pembelajaran menggunakan papan tulis, Lembar kerja anak (LKA) dan jari tangan saja untuk menghitungnya. Faktor Internal yaitu anak tidak tertarik bahkan anak terlihat bosan dan membutuhkan waktu yang lama untuk menyelesaikannya tugas berhitung dari guru, beberapa anak terlihat mengobrol dengan temannya, tidak memperhatikan pembelajaran dan penjelasan dari guru, serta ada anak yang bermain sendiri, bosan dengan media lembar kerja anak.

Melihat kenyataan dilapangan di atas, penulis merasa perlu mengadakan penelitian dengan judul "Meningkatan Kemampuan Berhitung Permulaan Angka 1-10 Melalui Media Sempoa”. Penulis berharap kemampuan anak dapat anak dapat meningkat melalui media sempoa sehingga berdampak positif terhadap aspek-aspek perkembangan lainnya. 


\section{Kemampuan Berhitung}

Menurut Munandar (1992), bahwa "Kemampuan merupakan daya untuk melakukan suatu tindakan sebagai hasil dari pembawaan dan latihan”. Robin dalam Munandar (1992) menyatakan hal yang senada bahwa "kemampuan merupakan suatu kapasistas atau kesanggupan dalam diri setiap individu di mana daya ini dihasilkan daripembawaan dan juga latihan yang mendukung individu dalam menyelesaikan tugasnya”. Menurut Suriasumantri (1982), "Berhitung merupakan dasar dari beberapa ilmu yang dipakai dalam setiap kehidupan manusia.

Menurut Wullan dkk (2013), dalam Jurnal Edukasi 2017, IV mengatakan "Berhitung merupakan suatu kegiatan melakukan, mengerjakan hitungan seperti menjumlah, mengurangi dan memanipulasi bilangan-bilangan dan lambang-lambang matematika" (Putri,2014). Berhitung permulaan merupakan salah satu kemampuan yang sangat penting bagi anak yang perlu dikembangkan dalam rangka membekali anak dikehidupannya di masa depan. Berhitung merupakan dasar dari beberapa ilmu yang dipakai dalam setiap kehidupan manusia. Mengingat begitu pentingnya kemampuan berhitung bagi manusia, maka kemampuan berhitung ini perlu diajarkan sejak dini, dengan berbagai media dan metode yang tepat sehingga tidak dapat merusak pola perkembangan anak. Pembelajaran matematika pada anak sudia dini haruslah melalui cara yang sederhana dan tepat serta dilakukan secara konsisten dan kontinu dalam suasana yang kondusif dan menyenangkan, maka otak anak akan terlatih untuk terus berkembang sehingga anak dapat menguasai, dan bahkan menyenangi matematika tersebut. (Susanto, 2011).

\section{Media Sempoa}

Menurut, Dudung, dalam Wulan dkk (2013), "Media pembelajaran merupakan suatu komponen sumber belajar yang mengandung bahan ajar instruksional yang bertujuan untuk memotivasi siswa dalam belajar. Adapun fungsi dan tujuan pengaplikasian media pembelajaran dalam mengembangkan kemampuan kognitif anak yaitu untuk memotivasi anak melakukan kegiatan pembelajaran, sebagai alat peraga untuk membantu memperjelas materi, untuk mengembangkan kreatifitas anak, untuk membantu mencapai tujuan 
pembelajaran yang maksimal, serta sebagai wahana permainan bagi anak usia dini.

Leslie J Briggs Lesle J. Briggs dalam Rusman (2009) menyatakan bahwa "Media pembelajaran sebagai "the physical means of conveying instructional content . . . . . . . book, films, videotapes, ect. Lebih jauh Briggs menyatakan media adalah "alat untuk memberi perangsang bagi peserta didik supaya terjadi proses belajar. Media pembelajaran merupakan salah satu alat komunikasi dalam proses pembelajaran. Dikatakan demikian karena didalam media pembelajaran terdapat proses penyampaian pesan dari pendidik kepada anak didik.

Daryanto, (2010), menyatakan, "Media pembelajaran adalah segala sesuatu yang dapat digunakan untuk menyalurkan pesan sehingga dapat merangsang perhatian, minat, pikiran, dan perasaan anak dalam kegiatan belajar untuk mencapai tujuan pembelajaran. Sempoa merupakan salah satu media pembelajaran yang dapat digunakan dalam meningkatkan kemampuan berhitung permulaan anak. Menurut Syifa, (2015) menyatakan bahwa sempoa (ada juga yang menyebutkan sipoa, cipoa, swipoa, simsuan, abacus atau sorokan), merupakan alat hitung tradisional seperti yang biasa digunakan di Jepang dan Cina. Berupa kotak segi empat yang dibagi menjadi dua bagian, atas dan bawah dengan manik-manik bernilai satu pada bagian bawah. Kelebihan dari sempoa menurut Khumaidah (2007), adalah menyeimbangkan otak kiri dengan otak kanan, meningkatkan konsentrasi dan meningkatkan rasa percaya diri.

Harahap (1998) menambahkan bahwa Sempoa adalah alat hitung sederhana untuk menjelaskan nilai tempat angka pada bilangan-bilangan dan dapat pula digunakan untuk operasi-operasi bilangan, seperti operasi penjumlahan dan operasi pengurangan. Rahmawati (2007:1) menyatakan bahwa Sempoa merupakan suatu alat yang dapat membantu untuk menghitung dengan cepat dan tepat.

\section{METODE}

Penelitian ini dilaksanakan pada tanggal 22 Oktober - 07 Desember 2018 dengan sumber data penelitian anak kelompok B yang berjumlah 16 orang. Jenis penelitian ini menggunakan penelitian tindakan kelas (Classroom 
action research). Desain dalam penelitian ini menggunakan Kemmis dan Taggart yang meliputi 4 tahap yaitu tahap perencanaan, tindakan, pengamatan dan refleksi. Dalam model Kemmis dan Taggart tindakan dan observasi dijadikan sebagai suatu kesatuan yang tidak dapat terpisahkan. Teknik pengumpulan data yang digunakan dalam penelitian ini adalah observasi, catatan lapangan dan dokumentasi.

Lembar instrumen yang telah disiapkan oleh peneliti berisikan indikatorindikator yang merupakan acuan dalam menilai kemampuan berhitung permula anak usia 5-6 tahun. Instrumen ini diisi oleh peneliti dan kolaborator dengan memberikan tanda check list $(\sqrt{ })$ pada setiap indikator yang sesuai dengan tingkatan perkembangan berhitung permulaan yang muncul pada anak.

Pengolahan data dalam penelitian ini menggunakan dua analisis data yaitu analisis data kuantitatif dan analisis data kualitatif. Analisis data kuantitatif menggunakan statistik deskriptif dengan cara membandingkan hasil yang diperoleh pada pra siklus sampai siklus II. Analisis data kualitatif dilakukan dengan cara menganalisis data dari hasil catatan lapangan, observasi dan dokumentasi dengan langkah-langkah reduksi data, display data dan verifikasi data.

\section{HASIL DAN PEMBAHASAN}

Berdasarkan analisis yang telah dilakukan secara kuantitatif dan kualitatif berdasarkan catatan lapangan, observasi dan catatan dokumentasi maka hasilnya adalah terdapat peningkatan kemampuan berhitung permulaan anak melalui media sempoa. Anak-anak mengalami peningkatan kemampuan berhitung permulaan pada indikator anak kemampuan menyebut bilangan 110, Kemampuan penjumlahan bilangan 1-10, Kemampuan pengurangan bilangan 1-10. Hal ini terlihat dalam proses pembelajaran, di mana ketika anak diminta menunjukkan membilang angka 1-10, anak mampu membilang dengan benar, ketikan anak diminta untuk menjumlahkan angka 1-10 maka anak dapat menjumlahkan dengan benar, dan di mana anak diminta menghitung pengurangan angka 1-10 maka anak dapat melakukannya dengan benar. 
Anak mampu membilang angka permulaan angka 1-10, terlihat dari antusias dan ekspresi anak-anak ketika salah berhitung angka 1-10 mereka akan meminta guru agar mengulangi berhitung angka permulaan dengan media sempoa tersebut. Pada siklus akhir yaitu siklus II keseluruhan aspekaspek kemampuan berhitung permulaan angka 1-10 ini berada pada kategori berkembang sangat baik (BSB), dimana anak-anak dinyatakan telah memiliki kemampuan berhitung permulaan angka 1-10 yang sudah berkembang sangat baik sebagai akibat dari proses penerapan media sempoa

Melihat hasil penelitian diatas, Berbicara tentang media sempoa dan kaitannya dengan kemampuan berhitung permulaan angka 1-10 sesuai dengan variabel yang diteliti oleh peneliti. Menurut peneliti metode sempoa dapat meningkatkan kemampuan berhitung permulaan anak usia 0-6 tahun, pernyataan ini dapat dibuktikan dengan hasil penelitian ini. Seperti yang sudah dikemukakan oleh para ahli bahwa dengan bermain melalui media sempoa dapat mampu mengembangkan semua aspek perkembangan anak, dan juga semua potensi yang anak miliki.

Hasil penelitian ini menujukkan bahwa media sempoa dapat meningkatkan kemampuan kognitif, Bahasa dan motorik anak yang termasuk dalam kemampuan berhitung angka permulaan anak sehingga membuat anak mampu berhitung dengan benar dan siap untuk belajar di tingkat sekolah dasar.

Data Peningkatan Kemampuan Berhitung Permulaan Angka 1-10 Anak Kelompok B di PAUD Naggalo Marannu, 2018

\begin{tabular}{|c|c|c|c|}
\hline NAMA & PRA SIKLUS & SIKLUS I & SIKLUS II \\
\hline NL & $50 \%$ & 66.67 & 91,67 \\
\hline RL & $50 \%$ & 66,67 & 83,33 \\
\hline AA & $75 \%$ & 83,33 & 91,67 \\
\hline KN & $33,33 \%$ & 66,67 & 83,33 \\
\hline ML & $58,33 \%$ & 75 & 83,33 \\
\hline SN & $33,33 \%$ & 66,67 & 83,33 \\
\hline AI & $75 \%$ & 83,33 & 91,67 \\
\hline IN & $25 \%$ & 58,33 & 75 \\
\hline LI & $50 \%$ & 66,67 & 83,33 \\
\hline EA & $25 \%$ & 50 & 75 \\
\hline TA & $25 \%$ & 58,33 & 75 \\
\hline GI & $66,67 \%$ & 75 & 83,33 \\
\hline CL & $25 \%$ & 58,33 & 83,33 \\
\hline MA & $75 \%$ & 75 & 83,33 \\
\hline NA & $33,33 \%$ & 58,33 & 75 \\
\hline AI & $41,65 \%$ & 58,33 & 75 \\
\hline Rata-rata Kelas & $\mathbf{4 6 , 3 5 \%}$ & $\mathbf{6 6 , 6 6 \%}$ & $\mathbf{8 2 , 2 9 \%}$ \\
\hline
\end{tabular}




\section{KESIMPULAN}

Berdasarkan hasil penelitian dan pembahasan yang sudah diuraikan pada bab IV di atas, maka dapat ditarik kesimpulan hasil penelitian sebagai berikut :

1. Pada hasil observasi awal, kemampuan berhitung angka 0-10 pada anak kelompok B di Paud Terpadu Naggalo Marannu Kota Mulia Kabupaten Puncak Jaya rata-rata baru mencapai 46\%. Setelah dilakukan perbaikan pembelajaran dengan menggunakan media sempoa sebanyak 2 siklus sebanyak 6 tindakan, maka terjadi peningkatan yakni : Pada siklus I kemampuan berhitung angka 0-10 pada anak-anak meningkat menjadi meningkat menjadi $66,66 \%$.

2. Pada siklus II kemampuan berhitung angka 0-10 anak kelompok B meningkat menjadi 82,29\% dan semua anak sebanyak 16 anak telah tuntas dan memenuhi kriteria ketuntasan minimum yang di harapkan yaitu sebesar $75 \%$.

Berdasarkan kesimpulan 1 dan 2 tersebut, maka dapat dikatakan bahwa melalui media sempoa kemampuan berhitung angka 0-10 pada anak kelompok B Paud Terpadu Naggalo Mulia Puncak Jaya dapat meningkat sesuai yang diharapkan mencapai nilai KKM yang telah ditentukan

\section{DAFTAR PUSTAKA}

Daryanto. (2010). Media Pembelajaran. Bandung: Satu Nusa.

Harahap, (1998). "Pandai Berhitung Dengan Sempoa”. Jakarta : Puspa Swara. Khumaidah, Nurul. (2007). Panduan Belajar Mental Aritmatika. Gresik: Master.

Munandar (1992). Mengembangkan Bakat dan Kreativitas Anak Sekolah. Jakarta : PT Grasindo

Putri, L. (2014). Upaya meningkatkan kemampuan berhitung permulaan menggunakan strategi bermain stick angka di Paud. Belia jurnal: Jurnal Ilmiah PG-PA UD IKIP Veteran Semarang, 2(2).

Rahmawati, Dyah. (2007). "Mental Aritmatika Sempoa”. Jakarta : Alex Media Komputindo.

Rusman. (2009). Manajemen Kurikulum, Cet.1. Jakarta :PT Rajagrafindo Persada.

Suriasumantri. (1982). Pusat Pembinaan dan Pengembangan Bahasa. Jakarta: Universitas Terbuka. 
Susanto, A. (2011). Perkembangan Anak Usia Dini. Jakarta: Kencana Prenada Media Group.

Syifa, F. M. dan N. D. Simatupang. (2015). Penggunaan sempoa dalam Pengembangan Kemampuan Berhitung Permulaan Anak. Skripsi. Surabaya: Universitas Negeri Surabaya.

Wulan, G. A. N., Priatna, D., \& Ismail, M. H. (2013). Meningkatkan Kemampuan Berhitung Permulaan Anak Usia Dini Melalui media Permainan Stick Angka. Cakrawala Dini: Jurnal Pendidikan Anak Usia Dini, 8(1). 